\title{
Gasotransmitters in Gametogenesis and Early Development: Holy Trinity for Assisted Reproductive Technology-A Review
}

\author{
Jan Nevoral, ${ }^{1,2}$ Jean-Francois Bodart, ${ }^{3}$ and Jaroslav Petr ${ }^{4}$ \\ ${ }^{1}$ Laboratory of Reproductive Medicine of Biomedical Center, Faculty of Medicine in Pilsen, Charles University in Prague, \\ Alej Svobody 1655/76, 32300 Pilsen, Czech Republic \\ ${ }^{2}$ Department of Histology and Embryology, Faculty of Medicine in Pilsen, Charles University in Prague, \\ Alej Svobody 1655/76, 32300 Pilsen, Czech Republic \\ ${ }^{3}$ Team Régulation des Signaux de Division, UMR 8576 CNRS, Université Lille 1, Sciences et Technologies, \\ FR 3688 CNRS, 59655 Villeneuve d'Ascq Cedex, France \\ ${ }^{4}$ Institute of Animal Science, Pratelstvi 815, 10400 Praha Uhrineves, Czech Republic
}

Correspondence should be addressed to Jan Nevoral; jan.nevoral@lfp.cuni.cz

Received 29 April 2016; Accepted 3 July 2016

Academic Editor: Michael D. Pluth

Copyright (c) 2016 Jan Nevoral et al. This is an open access article distributed under the Creative Commons Attribution License, which permits unrestricted use, distribution, and reproduction in any medium, provided the original work is properly cited.

Creation of both gametes, sperm and oocyte, and their fusion during fertilization are essential step for beginning of life. Although molecular mechanisms regulating gametogenesis, fertilization, and early embryonic development are still subjected to intensive study, a lot of phenomena remain unclear. Based on our best knowledge and own results, we consider gasotransmitters to be essential for various signalisation in oocytes and embryos. In accordance with nitric oxide $(\mathrm{NO})$ and hydrogen sulfide $\left(\mathrm{H}_{2} \mathrm{~S}\right)$ physiological necessity, their involvement during oocyte maturation and regulative role in fertilization followed by embryonic development have been described. During these processes, $\mathrm{NO}$ - and $\mathrm{H}_{2} \mathrm{~S}$-derived posttranslational modifications represent the main mode of their regulative effect. While NO represent the most understood gasotransmitter and $\mathrm{H}_{2} \mathrm{~S}$ is still intensively studied gasotransmitter, appreciation of carbon monoxide (CO) role in reproduction is still missing. Overall understanding of gasotransmitters including their interaction is promising for reproductive medicine and assisted reproductive technologies (ART), because these approaches contend with failure of in vitro assisted reproduction.

\section{Introduction}

Human reproductive medicine and assisted reproductive technologies (ART) have been gaining increasing significance, dealing with human reproduction failure. Doubtlessly, the oocyte and sperm are crucial cells for assisted reproduction because these haploid gametes are required to build a diploid zygote, capable of further development. Female and male gametes exhibit different morphological features and, excluding brought genome, they differently contribute to embryo formation. While centrosomes, small noncoding RNAs, and posttranslationally modified residual histones are sperm-inherited, oocytes provide mitochondria, mRNAs (distributed according to a specific pattern), histones, metabolic enzymes, and cytoplasmic factors to sustain development, as summarized elsewhere [1-5]. Hence, one has to consider the oocyte as a microenvironment filled with a precisely balanced cocktail of the numerous factors that are essential for embryonic development. Also, oocytes offer physical environments favourable to self-organizing process like division spindle assembly. Upon fertilization, a succession of mitotic divisions is triggered; the transition from maternal to zygotic mRNAs transcription and transformation of a low organized cellular mass into a blastocyst will occur prior to implantation. Together with gametogenesis and DNA integrity maintenance, these events are of high interest for ART. Indeed, any failure in these processes will impact severely the embryo's fate. Untangling the processes at the molecular and cellular levels is crucial for ART and we should underline that the effects of many contributors, besides the main regulators of gametogenesis and early embryogenesis, remain uncovered. 
Oocyte maturation, which can be simulated in in vitro conditions, deserves particular attention because meiotic division and achievement of developmental competence are finalized during this short and extremely important period (summarized in [5]). The quality of matured oocytes is decisive for the fertilization rate, as a result of sperm penetration and complex oocyte changes including cortical granule exocytosis-prevented polyspermy and oocyte activation for embryonic development [6-8]. In fact, the early embryonic development, where high-quality blastocyst is optimal for embryo transfer into the recipient body, is decisive for the success of ART $[9,10]$. Numerous factors have been identified to play different roles in chromosome segregation and developmental competence achievement, regulating kinases, structural cytoskeletal proteins, enough histones, and second messengers (cAMP, cGMP, and $\mathrm{Ca}^{2+}$ ions) [11-14]. In addition to these known key factors, gaseous molecules with signal transduction ability, hence named gasotransmitters [15-17], have been involved in the oogenesis as well [18, 19]. Their impact is acknowledged along with a better understanding of gasotransmitters' signalling pathways. Moreover, recent observations point out imperfect in vitro imitation [20] and some gasotransmitter signalisation seems to be lacking in complete gametes' maturation and early embryogenesis.

Only matured oocytes are able to go through in vitro fertilization, a key technique of assisted reproduction [21]. Fertilization consists in the interactions of male and female gametes leading to embryonic development. The high cell division rate, typical of this period, is highly sensitive to wellorchestrated cell cycle regulation $[2,22,23]$. Oocyte maturation and early embryonic development persist as delicate steps for in vitro approaches, calling for ART improvement. Nevertheless, gasotransmitters rise expectations due to their broad physiological effect and promising results of gasotransmitters supplementation.

The aim of this review is to compare the biological necessity of all three gasotransmitters in the oocyte and embryo, observing their in vitro culture in ART, as a key factor for creating a new individual. This comparison highlights protein posttranslational modifications as crucial molecular action of gasotransmitters during oogenesis and preimplantation embryonic development.

\section{Gasotransmission in Female Reproductive Processes}

2.1. NO as a "Yes Signal" for Fertilization and Early Development. Only matured gametes, which underwent adequate changes, are capable of fertilization. These changes involve especially oocyte maturation, sperm capacitation, and acrosome reaction and are an essential prerequisite for both successful fertilization and further embryonic development. Biochemical changes regulate gametes' changes and their interactions during fertilization process. Originally, these changes were believed to be exclusively regulated via kinase signalling, such as protein kinase A- (PKA-) M-phase/maturation promoting factor- (MPF) mitogenactivated protein kinase (MAPK) and calmodulin-dependent protein kinase II (CaMKII), either directly dependent or indirectly regulated by molecules of second messengers, $\mathrm{Ca}^{2+}$ and CAMP. In addition to these two messengers, the involvement of NO, a small gaseous molecule, in cell signalling of physiological processes has been described [24, 25]. Along with $\mathrm{NO}$, gasotransmitters $\mathrm{H}_{2} \mathrm{~S}$ and $\mathrm{CO}$ were suggested to participate in the above-mentioned processes as well $[17,26-$ 28] (see Figure 1).

NO represents the most read-up gasotransmitter, with ability to regulate molecular processes in gametes and embryo [29-31]. All NO synthases, that is, endothelial (eNOS), neuronal (nNOS), and inducible (iNOS), are present in mammalian oocyte with various subcellular localization, where they are essential for endogenous production of NO and its cell signalisation $[32,33]$. NO action leads to ovulation of matured and fertilizable oocytes [31, 32] as a result of reinitiation of oocyte meiosis and correct oocyte maturation $[18,31,32]$. Accordingly, NO level in oocytes of young mice is significantly higher than old animals and NO antiaging effect is obvious [34]. On the contrary, increased eNOS expression accompanies improved mouse oocyte quality after estrogen administration [35]. One of NO action modes, S-nitrosylation of proteins, has been observed in oocytes during meiotic maturation [36]. However, $\mathrm{NO}$ is able to stimulate soluble guanylate cyclase (sGC), which is a NOspecific receptor, in cGMP production and thus $\mathrm{NO}$ increases protein kinase $\mathrm{G}(\mathrm{PKG})$ activity [37-40]. On the other hand, S-nitrosylation of sGC affects the decreasing responsiveness to NO in somatic cells and molecular mechanism-dependent dual effect of NO is obvious [41]. In contrast to oocyte maturation [38], NO-sGC-cGMP-PKG signal pathway is capable of inducing spontaneous oocyte activation and subsequent parthenogenetic development [42]. NO-induced oocyte activation indicates a pulsation pattern of $\mathrm{NO}$ action in porcine oocytes [43]. Based on an observation of Xenopus oocytes, the parthenogenetic NO effect is $\mathrm{Ca}^{2+}$-dependent and occurs due to MAPK inactivation [44].

While NO might promote but is dispensable for Xenopus and mammals oocyte activation, NO is essential for oocyte activation event during the fertilization process in sea urchin oocytes [45]. In accordance with this variable effect, cortical granules exocytosis has been reported in Xenopus oocytes [44] but not in porcine oocytes [46]. The interspecies differences of $\mathrm{NO}$ action during fertilization are obvious and NO seems to be even nonessential during mammalian fertilization (Figure 2). The ambiguous NO necessity could be a result of a more diverse NO effect when $\mathrm{NO}$ is associated with inflammation and/or oxidative stress $[47,48]$. Accordingly, the role of NO during subsequent embryonic development after fertilization remains controversial [49-51] for inflammation (endometriosis), accompanying NO [52, 53] and protein nitration [54]. However, creation of secondary products of NO interactions seems to be one of possible mechanisms of NO negative action [55]. The physiological role of NO in embryogenesis is still unexceptionable when $\mathrm{NO}$ is involvement in embryonic stem cell differentiation through transcriptional factors [56]. Therefore, NO is able to be considered as trigger for oocyte maturation and fertilization as well as subsequent embryonic development. 


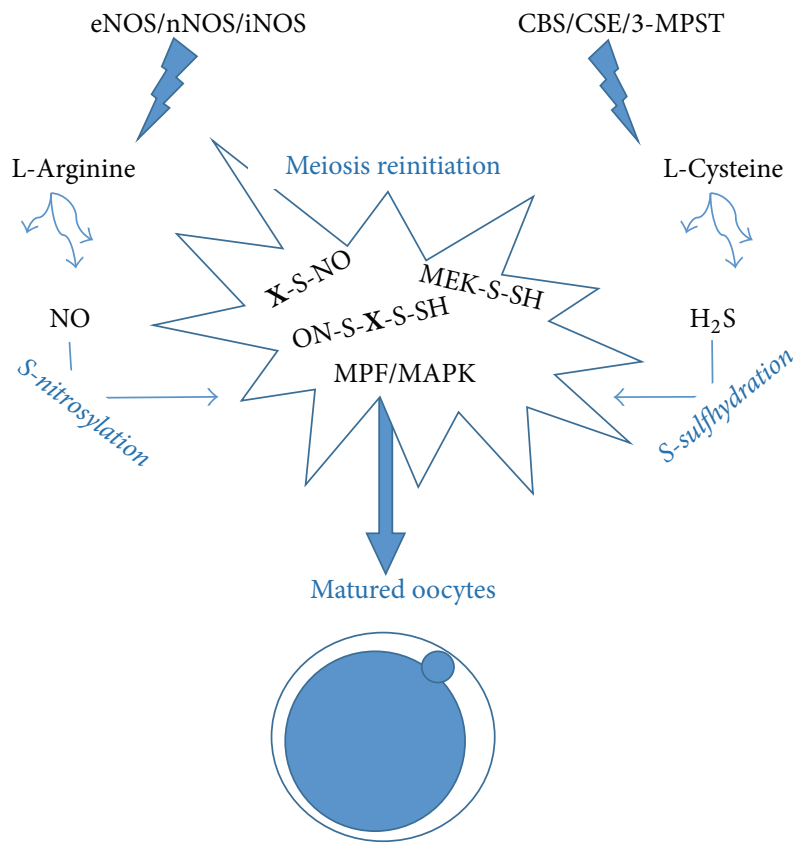

FIGURE 1: Gasotransmission in oocytes, resulting in S-sulfhydration and nitrosylation of various factors. Both gasotransmitters NO and $\mathrm{H}_{2} \mathrm{~S}$ are enzymatically released, respectively, from L-arginine and L-cysteine. Subsequently, NO- and/or $\mathrm{H}_{2} \mathrm{~S}$-posttranslationally modified proteins lead to MPF/MAPK-orchestrated meiotic maturation reinitiation (equal to GVBD, germinal vesicle breakdown) and completion (with extruded polar body and small particles visible in perivitelline space). S-sulfhydration of MEK, upstream MAPK kinase, is known [61] and more S-sulfhydrated factors are considered. In addition to S-sulfhydration, S-nitrosylation seems to be exclusive mechanism of NO-regulated oocyte maturation [34]. Disclosure of complete "S-sulfhydration" and "S-nitrosylation" is still lacking ( $\mathbf{X}$-S-SH, $\mathbf{X}$-S-NO) and we can assume wide protein index underwent this posttranslational modifications as well as NO$\mathrm{H}_{2} \mathrm{~S}$ intraprotein cross-talking (HS-S-X-S-NO).

2.2. $\mathrm{H}_{2} \mathrm{~S}$ in Gametogenesis and Embryo Development. Ssulfhydration, another gasotransmitter-derived posttranslational modification, is supposed to be a prime way of $\mathrm{H}_{2} \mathrm{~S}$ molecular action $[57,58]$ without known $\mathrm{H}_{2} \mathrm{~S}$-specific receptors. In contrast to $\mathrm{NO}$, little is known about $\mathrm{H}_{2} \mathrm{~S}$ and $\mathrm{S}$ sulfhydration involvement in gametogenesis and embryonic development. Nevertheless, all three $\mathrm{H}_{2} \mathrm{~S}$-releasing enzymes, CBS, CSE, and 3-MPST, were observed in porcine oocyte and surrounding cumulus cells [59]. This observation is in accordance with earlier finding of $\mathrm{H}_{2} \mathrm{~S}$ involvement in folliculogenesis and oocyte maturation $[19,20]$. The necessity of $\mathrm{H}_{2} \mathrm{~S}$ in matured oocytes interferes with the contribution to developmental competence acquirement and subsequent embryonic development [20]. In addition, there is the observation of a protective effect of $\mathrm{H}_{2} \mathrm{~S}$ against oocyte aging and $\mathrm{H}_{2} \mathrm{~S}$-positively affected further embryonic development [60]. Physiological action of endogenously released $\mathrm{H}_{2} \mathrm{~S}$ immediately in oocyte has been described and modified kinase activity of MPF and MAPK has been observed [20, 59, 60]. S-sulfhydration of these kinases and their upregulated factors are presumable. Activating S-sulfhydration

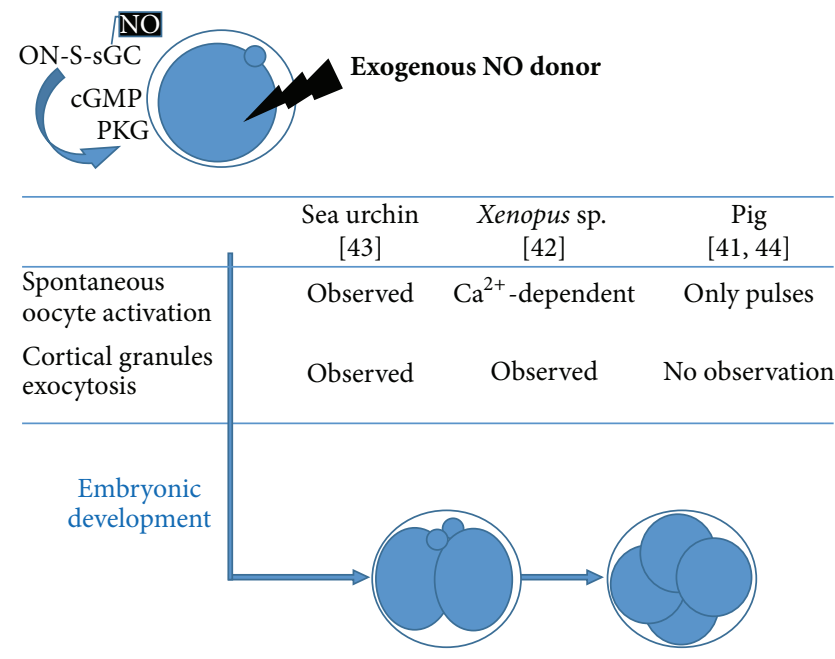

FIGURE 2: NO action in oocyte activation is evolutionary inconsistent. The NO/sCG/cGMP/PKG signal pathways are presumed, where dual NO effect on sCG, resulting in its S-nitrosylation and NO binding, is expectable. Obviously, dependency of fertilization and oocyte activation, followed by cleavage and the second polar bod extrusion, is shaded in evolutionary more developed organisms, where fulfilment of certain conditions $\left(\mathrm{Ca}^{2+}\right.$ presence, pulsative character of NO) is necessary.

of MEK, leading to MAPK signalling [61], confirms this assumption and the findings mean that S-sulfhydration is crucial for enzyme activity and shift its significance to protein phosphorylation.

However, in contrast to the essential and protective effect of $\mathrm{H}_{2} \mathrm{~S}$ in mammalian oocytes, our own observation of oxidative stress-like effect of $\mathrm{H}_{2} \mathrm{~S}$ in Xenopus oocytes indicates less conservative evolutionary mechanism through species. Moreover, some findings support that $\mathrm{H}_{2} \mathrm{~S}$ action is at least comparable to reactive oxygen species (ROS) throughout reactive sulfide species (RSS) creation [62-64].

Although the role of the third gasotransmitter, CO, remains uncovered, the necessity of gasotransmitters for male and female reproduction including fertilization and embryonic development is unquestionable. Accordingly, Snitrosylation and sulfhydration of sulphur amino acid cysteine seem to be crucial protein posttranslational modifications for reproductive processes and their understanding brings relevant possibilities for ART.

\section{An Increasing Attractiveness of S-Nitrosylation and S-Sulfhydration}

Decades of research have established a high potential for $\mathrm{NO}$ and S-nitrosylation in controlling cellular mechanisms. Indeed, both $\mathrm{NO}$ and $\mathrm{H}_{2} \mathrm{~S}$ might engage in protein shortlived covalent reactions, which modulate proteins structure and functions. NO builds its signalling activity by binding to sulfhydryl groups of cysteine residues in target proteins. The latter process is called S-nitrosylation. In a similar manner, S-sulfhydration is a posttranslational modification of specific 
residues, through the formation of persulfide (-SSH) bonds. Both sulfhydration and S-nitrosylation are reversible.

There is a broad spectrum of S-nitrosylated proteins. An exhaustive list would be beyond the scope of this review. Nevertheless, it is to note that nitrosylated proteins include cytoskeleton, cell migration, cell cycle, and antiapoptotic proteins, as well as proteins involved in transcription and protein synthesis [65-69]. In a similar way, protein-SSH formation is now admitted to mediate in a fundamental manner the cellular signalling by $\mathrm{H}_{2} \mathrm{~S}$, based on the detection of S-sulfhydrated proteins and on the demonstration of their perturbed functions [70]. Spatial environments of the modified residues drive the impact of S-sulfhydration on protein function. For example, it may protect residues from oxidation under oxidative stress and therefore may sustain protein activities.

3.1. From Cell Cycle to Implantation, Potential Roles for SNitrosylation. Therefore, S-nitrosylation is a well-established posttranslation modification, whose potential involvements at physiological level in oocytes and embryos go from cell cycle regulation (meiotic transition, segmentation) to embryo survival and implantation.

Indeed, S-nitrosylation targets can be found within main modulators of meiosis progression or cell cycle progression and their regulators. Though the $\mathrm{M}$-phase promoting factor, made up with cyclin $\mathrm{B}$ and cyclin-dependent kinase 1 (CDK1), was not reported to be itself S-nitrosylated, the S-nitrosylation of CDKs was observed for CDK2, CDK5, and CDK6 [71-73]. While CDK2-nitrosylation increases its activity independently of any effects on protein levels expression, the effect of S-nitrosylation on CDK5 and CDK6 remains elusive. S-nitrosylation of cyclin B was sought in HL-60 cells, but not observed [72]. No S-nitrosylation was reported for polo-like kinases (PLKs), anaphase promoting factor/cyclosome (APC/C), WEE1, and MYT1, which are among the close regulators of MPF. Nevertheless, the dual specificity cell division cycle 25 phosphatase (CDC25), which is the main activator of MPF, is clearly impacted since its S-nitrosylation annihilates its phosphatase activity ([71, 74]; Gelaude and Bodart: personal observations).

Beyond the cell cycle regulators, S-nitrosylation has been called to play a role in preimplantation embryos and implantation. Microenvironmental presence of NO was reported to contribute to the pathologic effects of endometriosis on the development potential of embryos. In this context, NO effects on embryo survival could either rely upon Snitrosylation, $\mathrm{NO} / \mathrm{GC} / \mathrm{cGMP}$ or peroxynitrite formation. Lee et al. [50] suggested that the apoptotic effects of excessive $\mathrm{NO}$ on embryos were related to S-nitrosylation rather than to any other mechanisms. These effects were closely associated with lipid-rich organelles (mitochondria and endoplasmic reticulum) [50, 75]. Regarding implantation, NO was shown to influence trophoblasts motility $[76,77]$. It was further suggested that the effects of NO on trophoblast migration and invasion, which are critical processes for the successful embryonic development, were mediated by nitrosylation of the matrix metalloprotease MMP9 [78]. Indeed, while MMP9 has been reported to be nitrosylated [79], it was colocalized with iNOS and S-nitrosylated proteins at the leading edge in trophoblast [78]. Finally, the trophoblast also appeared to be protected from apoptosis via S-nitrosylation of caspase 3 [80].

Thus, S-nitrosylation of proteins might play pivotal roles throughout the early development, modulating cell cycle, trophoblast motility, and embryo survival (Table 1).

\subsection{S-Sulfhydration as Another Modulator of Enzymatic} Activities. The impacts of $\mathrm{H}_{2} \mathrm{~S}$ and $\mathrm{S}$-sulfhydration have been addressed and considered to a lesser extent, mainly due to the lack of methodologies [81]. Since the specification of protein S-sulfhydration sites has been enabled, increasing evidence has come to underline the ability of Ssulfhydration to enhance or impair an enzymatic activity. Ssulfhydration was reported to impair the activity of KEAP1 [82], while it increases the activity of $\mathrm{K}_{\mathrm{ATP}}$ and $\mathrm{Ca}^{2+}$ channels, glyceraldehyde 3-phosphate dehydrogenase (GAPDH), nuclear factor $\kappa \mathrm{B}(\mathrm{NF}-\kappa \mathrm{B})$, and MAPK/ERK kinase 1 (MEK1) [57, 61, 82-84]. In addition to the above-mentioned S-sulfhydrated proteins, S-sulfhydration of cystathionine $\beta$-synthase (CBS) and cystathionine $\gamma$-lyase (CSE), $\mathrm{H}_{2} \mathrm{~S}$ releasing enzymes, has been observed [57] and existence of feedback in $\mathrm{H}_{2} \mathrm{~S}$ production is supported.

Protein phosphatase serves as points of flexibility and crucial regulation in network signalling. Evidence had raised the fact that it might be particularly subject to S-sulfhydration. Among the phosphatase types involved in early embryogenesis and/or signalling pathways and whose activity might be modulated by S-sulfhydration are phosphatase and tensin homolog (PTEN), protein-tyrosine phosphatase 1B (PTP1B), and aforementioned CDC25. Protein phosphatase PTEN is requested at early steps for proper embryonic development [85]. In the case of PTEN, S-sulfhydration was reported to maintain the activity of the phosphatase [86], by preventing its S-nitrosylation, which would result in protein degradation [87]. PTP1B belongs to the family of ErbB, involved in numerous signalling pathways modulating proliferation, adherence, migration, or survival. PTP1B was shown to be inactivated by S-sulfhydration of cysteine C215, located in its catalytic site [88].

Also, CDC25 might be sulhydrated and inactivated presumably by modification of the cysteine in its active site [89]. There is no direct evidence for CDC25 sulfhydration, but since organosulphur compounds inhibit CDC25A and promote G2/M arrest [90] and CDC25 are targeted by ROS and S-nitrosylation, CDC25 are likely to be S-sulfhydrated [91]. Further studies are obviously needed to gather an exhaustive list of S-sulfhydrated proteins, and one might first focus on proteins, which have been already reported as being S-nitrosylated. MKP1, ERK1, CDK2 and CDK5, CDC25, and MMP9 appear as appealing candidate (Table 1). Indeed, evidences have been raised for cross-talk between Ssulfhydration and S-nitrosylation for many proteins.

3.3. A Cross-Talk of S-Sulfhydration and S-Nitrosylation? Many protein sites have been reported to undergo either S-nitrosylation or S-sulfhydration. As an example, the residue cysteine $\mathrm{C} 150$ in GAPDH had been found either S-nitrosylated or S-sulfhydrated [54, 92-94]. Susceptibility 
TABLE 1: Examples of S-nitrosylated and/or S-sulfhydrated proteins.

\begin{tabular}{|c|c|c|c|c|c|}
\hline Protein & Sulfhydration site & $\begin{array}{c}\text { Sulfhydration effect on } \\
\text { function }\end{array}$ & $\begin{array}{l}\text { Nitrosylation } \\
\text { site }\end{array}$ & $\begin{array}{c}\text { Nitrosylation effect on } \\
\text { function }\end{array}$ & References \\
\hline MKP1 & n.d. & n.d. & $\mathrm{C} 258$ & Stability of protein & Guan et al., 2012 [130] \\
\hline ERK1 & n.d. & n.d. & C183 (potential) & $\begin{array}{c}\text { Prevention of } \\
\text { phosphorylation }\end{array}$ & Feng et al., 2013 [131] \\
\hline CDK2 & n.d. & n.d. & n.d. & Increase of kinase activity & Kumar et al., 2010 [72] \\
\hline CDK5 & n.d. & n.d. & n.d. & n.d. & Foster et al., 2009 [71] \\
\hline CDC25 & n.d. & n.d. & n.d. & Loss of phosphatase activity & $\begin{array}{c}\text { Foster et al., } 2009 \text { [71]; } \\
\text { Majumdar et al., } 2012 \text { [74] }\end{array}$ \\
\hline MMP9 & n.d. & n.d. & n.d. & Increase of activity & Harris et al., 2008 [78] \\
\hline PTP1B & C215 & $\begin{array}{c}\text { Reduction of phosphatase } \\
\text { activity }\end{array}$ & n.d. & n.d. & Krishnan et al., 2011 [88] \\
\hline PTEN & $\mathrm{C} 71, \mathrm{C} 124$ & $\begin{array}{l}\text { Maintenance of enzyme } \\
\text { activity and prevention of } \\
\text { further oxidation by NO }\end{array}$ & $\mathrm{C} 83$ & $\begin{array}{c}\text { Promotion of survival } \\
\text { signal and protein } \\
\text { degradation }\end{array}$ & $\begin{array}{l}\text { Kwak et al., } 2010 \text { [87]; } \\
\text { Ohno et al., } 2015 \text { [86] }\end{array}$ \\
\hline Actin & n.d. & $\begin{array}{l}\text { Increase of polymerization } \\
\text { activity }\end{array}$ & Cys 374 & $\begin{array}{l}\text { Decrease in polymerization } \\
\text { activity and network } \\
\text { formation }\end{array}$ & $\begin{array}{l}\text { Dalle-Donne et al., } 2000 \\
\text { [100]; Mustafa et al. } 2009 \\
\text { [57]; Thom et al., 2008 [101] }\end{array}$ \\
\hline MEK1 & C341 & $\begin{array}{c}\text { Facilitation of Parp } \\
\text { activation }\end{array}$ & n.d. & Loss of kinase activity & $\begin{array}{c}\text { Ben-Lulu et al., } 2014 \text { [73]; } \\
\text { Zhao et al., } 2014 \text { [61] }\end{array}$ \\
\hline Parkin & n.d. & Increase of activity & n.d. & Decrease of activity & $\begin{array}{l}\text { Chung et al., } 2004 \text { [95]; } \\
\text { Vandiver et al., } 2013 \text { [96] }\end{array}$ \\
\hline GAPDH & $\mathrm{C} 150$ & $\begin{array}{l}\text { Increase of the activity } \\
\text { sevenfold }\end{array}$ & $\mathrm{C} 150$ & $\begin{array}{l}\text { Inhibition of glycolytic } \\
\text { activity }\end{array}$ & $\begin{array}{c}\text { Greco et al., } 2006 \text { [93]; Hao } \\
\text { et al., } 2006 \text { [94]; Hara et al., } \\
2005 \text { [92]; Mustafa et al., } \\
2009 \text { [57] }\end{array}$ \\
\hline
\end{tabular}

for both modifications may strike root in the chemical properties of the involved thiols by S-nitrosylation and Ssulfhydration [81]. If S-sulfhydration and nitrosylation can occur on reactive cysteine residues, they frequently involve the same residue, generally by promoting different and opposing effects. Indeed, S-nitrosylation typically reduces cysteine thiols reactivity while S-sulfhydration increases cysteine thiols reactivity, thereby making them more nucleophilic. For instance, S-sulfhydration and nitrosylation on the same sites have been reported for GAPDH, Parkin, and the p65 subunit of NF- $\kappa \mathrm{B}$ (nuclear factor- $\kappa \mathrm{B}$ ) (Table 1 ). The increase of GAPDH activity stimulated by $\mathrm{S}$-sulfhydration is antagonized by nitrosylation, which impairs the glycolytic activity of the enzyme [54, 92-94]. Similarly for Parkin, the S-nitrosylation impairs the enzyme activity whereas sulfhydration stimulates it $[95,96]$.

S-nitrosylation and sulfhydration both regulate the p65 subunit of the antiapoptotic transcription factor NF- $\kappa \mathrm{B}$, which provided quite a school-case for the interplay of Snitrosylation and sulfhydration [82]. S-sulfhydration of NF$\kappa \mathrm{B}$ has been reported to inhibit apoptosis. Persulfidation of cysteine 38 of p65 unit of NF- $\kappa \mathrm{B}$ promotes binding of NF$\kappa \mathrm{B}$ to the coactivator ribosomal $\mathrm{S} 3$, thereby increasing its binding to promoters of antiapoptotic genes. Also, cysteine 38 persulfidation might function as the molecular "key" by which hydrogen sulfide prevents NF- $\kappa$ B pathway activation in ox-LDL-induced macrophage inflammation by impairing NF- $\kappa \mathrm{B}$ p65 phosphorylation, nuclear translocation, and, therefore, DNA binding activity [97]. One has to note that $\mathrm{NF}-\kappa \mathrm{B}$ S-sulfhydration may not account for all the protective effects of $\mathrm{H}_{2} \mathrm{~S}$ towards inflammation. Subsequent to sulfhydration, nitrosylation of $\mathrm{p} 65$ reversed the activation of NF- $\kappa \mathrm{B}$ targets [98, 99].

Similarly, actin, whose modifications of properties are requested for the rapid cadence of cytokinesis during early embryogenesis, is nitrosylated or sulfhydrated. While Ssulfhydration of actin resulted in an increase of filament polymerization [57], S-nitrosylated actin exhibited a decrease in polymerization activity and thus an impairment in actin network formation $[100,101]$. Actin-binding proteins such as profilin [101] and cofilin [102] are also subject to Snitrosylation and may contribute through the latter modifications to modulate the remodelling of the actin network. Thus, if we are to compare S-sulfhydration and nitrosylation, we should mainly outline that (1) proteins are rather $S$ sulfhydrated than S-nitrosylated and (2) nitrosylation is more likely to inhibit and impair protein functions (Table 1).

One may also hypothesize that the sequence of $\mathrm{S}$ nitrosylation and sulfhydration could provide a way for a fine tuning of signalling pathways and cellular functions regulation. Because protein S-nitrosylation can foster intramolecular disulfide bond formation, a protein S-nitrosylation event might promote the formation of a more enduring Ssulfhydration reaction. Moreover, S-sulfhydration of eNOS and its increased activity have been described [103]. Supervision of $\mathrm{Ca}^{2+}$ influx and availability of eNOS, $\mathrm{Ca}^{2+}$-dependent, 
is another mechanism of $\mathrm{H}_{2} \mathrm{~S}$-controlled $\mathrm{NO}$ creation [104]. Likewise, reverse $\mathrm{NO}$ modulation effect on $\mathrm{H}_{2} \mathrm{~S}$ releasing is assumed; however, it has not been uncovered so far.

\section{Perspectives of Gasotransmitters for Assisted Reproductive Technologies}

4.1. About Recent Reproductive Medicine. With respect to the above-described posttranslational modifications, the causality of some of the phenomena is explained. Assisted reproductive technologies (ART), as a medicinal approach to the solution of human infertility, are a field where the posttranslational modifications and their consequences could be utilized.

Embryos by produced in vitro by ART show differences compared to the in vivo grown embryos. Routinely used ART techniques, such as in vitro fertilization (IVF) or intracytoplasmic sperm injection (ICSI), may affect embryonic development differentially on cellular and molecular levels. Moreover, individual approaches are not equal where a slight delay of early embryonic development of IVFproduced human embryos compared to those fertilized by ICSI has been described $[105,106]$. An alteration of embryonic chromatin modifications, including posttranslational modifications of nucleosomal proteins, essential for genome reprogramming and successful development into blastocyst, is a possible explanation of this phenomenon [107-109]. To this respect, gasotransmitter involvement could be justly considered.

Supplementation of culture media with donors of NO or $\mathrm{H}_{2} \mathrm{~S}$ improves embryonic development in vitro [20, 58, 110]. The necessity of physiological NO production has been demonstrated for in vitro fertilization and embryo culture [111-113]. Moreover, NO plays a role in the second meiotic block release and oocyte activation [42, 43, 114]. The suppression of $\mathrm{H}_{2} \mathrm{~S}$ physiological production even leads to oocyte maturation failure [59]. Therefore, precise supplementation of $\mathrm{NO}$ and $\mathrm{H}_{2} \mathrm{~S}$ allows optimizing fertilization conditions [112] as well as relieving embryonic development defects. However, the molecular mechanisms are not known and target system is questionable.

4.2. Epigenetic Dimension of Gasotransmitters. S-nitrosylation, one of the above-mentioned NO-derived protein posttranslational modifications, affects direct chromatin modification, namely, tyrosine nitration of nucleosomal core histones [115]. Histone modification via NO is supposed to be decisive for gene activity [116]; however, final effect of histone nitration remains unclear [117]. In addition to S-nitrosylation, core histone is affected by acetylation and methylation $[118,119]$ and some evidence (mentioned below) indicates that $\mathrm{NO}$ and/or $\mathrm{H}_{2} \mathrm{~S}$ could be indirectly required in upstream signalling of these modifications. Accordingly, influencing histone modifying upstream enzymes is another $\mathrm{NO} / \mathrm{H}_{2} \mathrm{~S}$-modulated chromatin gene activity. Hereby, NO interacts with histone deacetylases (HDACs) when their activity is inhibited by NO in neurons [120]. On the other hand, NO is capable of activating Sirtuin 1 (SIRT1), one of $\mathrm{NAD}^{+}$-dependent HDACs [121]. Similarly, $\mathrm{H}_{2} \mathrm{~S}$ has been described as a potent activator of SIRT1 [122]. Presumably, Snitrosylation and S-sulfhydration are responsible for $\mathrm{NO}$ and $\mathrm{H}_{2} \mathrm{~S}$ effect, respectively. On the other hand, $\mathrm{NO} / \mathrm{H}_{2} \mathrm{~S}$-derived modifications do not seem to be strictly upstream, because $\mathrm{H}_{2} \mathrm{~S}$ releasing stimulated by resveratrol, a strong activator of SIRT1, has been recently observed [123].

The above-mentioned SIRT1 is responsible for modifications of both histone and nonhistone targets [124-126] and through modulation of its activity it brings a broad spectrum of S-nitrosylation and sulfhydration effect. In addition to histone deacetylation, complex SIRT1 signalling leads to histone methylation and thus chromatin stabilization, which is, however, accompanied by gene silencing (summarized in [127]). Apparently, gasotransmitters are involved in wide epigenetic regulations, affecting gene expression without changes in gene sequences themselves. Some evidence indicates targeted chromatin modulation and transcriptional activation of certain genes $[128,129]$, due to a molecular mechanism which is yet unknown.

4.3. Delicacy of Gasotransmitter Involvement in Epigenetic Regulation. In contrast to the lifespan beneficial genome stability, embryonic genome reprogramming requires transcriptional activity, nevertheless, followed by DNA damage-prone euchromatin creation, marked by histone acetylation [132135]. Therefore the equilibrium between chromatin stability and transcriptional activity is obviously the compromise for successful embryonic development. The dual effect of NO and $\mathrm{H}_{2} \mathrm{~S}$ on HDACs and $\mathrm{NAD}^{+}$-dependent HDACs $[136,137]$ and the delicate balance between them, obvious in somatic cells [138], could be the key to embryonic genome activation and impeccable further embryogenesis.

In accordance with presumption of $\mathrm{H}_{2} \mathrm{~S}$-epigenetically affected embryogenesis, cell cycle and proliferation are affected by $\mathrm{H}_{2} \mathrm{~S}$ as well $[139,140]$. The involvement of $\mathrm{H}_{2} \mathrm{~S}$ in regulation of specific promoters has been described in vascular smooth muscle cells [141]. Interestingly, teneleven translocation (Tet) proteins, factors playing a role in epigenetics of early embryo [142], are included in described $\mathrm{H}_{2} \mathrm{~S}$-modulated genes [143]. Although there are evidences of $\mathrm{H}_{2} \mathrm{~S}$-derived epigenetic regulation of cell cycle, the characterization of $\mathrm{H}_{2} \mathrm{~S}$-caused chromatin modifications remains clean.

In general, presence of $\mathrm{NO}$ and $\mathrm{H}_{2} \mathrm{~S}$ has been reported in mammalian oocytes and embryos as well $[32,59,144]$ and their cross-talk due to S-nitrosylation and sulfhydration was reported, where their necessity is assumed. Meanwhile, there is poor knowledge of all gasotransmitters' potentiality, for example, (a) direct $\mathrm{H}_{2} \mathrm{~S}$-derived S-sulfhydration of core histones, (b) $\mathrm{NO} / \mathrm{H}_{2} \mathrm{~S} / \mathrm{SIRT} 1$ axis, leading to chromatin equilibrium between an adequate transcriptional gene activity and genome stability, and (c) absent knowledge of CO involvement in epigenetics-driven embryogenesis. Regarding $\mathrm{CO}$, its molecular action remains fully unidentified and CO-derived modifications have not yet been completely explained.

Obviously, understanding the molecular mechanism of $\mathrm{NO} / \mathrm{H}_{2} \mathrm{~S}$ interaction and HDACs-modified embryonic chromatin offers a possibility for improvement of in vitro 
embryo production via a gasotransmitter tool. A complete understanding of the cross-talk between all gasotransmitters, including CO, is necessary and a holistic approach should be emphasized.

\section{Conclusion}

This review summarizes the recent knowledge of gasotransmitters' action in maturing oocytes and early embryonic development, in various animal species, including sea urchin, Xenopus, and mammalian models. Current observations point out the necessity of $\mathrm{NO}$ and $\mathrm{H}_{2} \mathrm{~S}$ in these processes; however, the role of $\mathrm{CO}$ remains unexplained.

Based on our best knowledge, the observations, performed on amphibian and mammalian female reproduction, enlightened various species-specific biological action of both $\mathrm{NO}$ and $\mathrm{H}_{2} \mathrm{~S}$. Nevertheless, the gasotransmitter-derived posttranslational modifications are shared throughout the studied animal models. Both S-nitrosylation and S-sulfhydration may be required for adequate protein activities/functions and therefore, patterns of posttranslational modifications create $\mathrm{NO}$ - and $\mathrm{H}_{2} \mathrm{~S}$-modulated proteome in oocytes and embryos. Importantly, most of gasotransmitter-modified proteins may not have been yet described. Although the understanding is limited, S-nitrosylation and sulfhydration seem to be equal to other posttranslational modifications' impact. In contrast to the wide spectrum of kinases mediating phosphorylation and regulation of various proteins, $\mathrm{NO}$ and $\mathrm{H}_{2} \mathrm{~S}$ decide on the activity of a comparable spread of proteins. However, other alternative molecular mechanisms could be considered, often epoch-making, such as possible ROS-generating $\mathrm{H}_{2} \mathrm{~S}$ due to RSS creation [62, 63].

In addition to above-mentioned absence of insight, $\mathrm{CO}$, the third known gasotransmitter, is still unexplored and its molecular involvement in gametogenesis and embryogenesis waits for verification. The principle of $\mathrm{CO}$ molecular action is unknown and $\mathrm{NO}$ and $\mathrm{H}_{2} \mathrm{~S}$ like posttranslational modifications can be presumed. The evolutionary permanence of $\mathrm{CO}$ biological effect is questionable, with respect to the existing recognition traits of $\mathrm{NO}$ and $\mathrm{H}_{2} \mathrm{~S}$. In addition to the single $\mathrm{CO}$ action, the interaction of all gasotransmitters offers infinite consequences resulting in various effects in gametes and embryos. Three gasotransmitters have been described so far and some other small molecules, such as sulphur dioxide $[145,146]$ or hydrogen $[147,148]$, exhibit possible gasotransmitter features as well.

Obviously, the understanding and further study of gasotransmitters are necessary for the advancement of human ART. The in vitro technologies are based on a simulation of in vivo conditions, still lacking undefined factors. Gasotransmitters are among the essential molecules, missing in in vitro protocols where their failure is appreciable. However, their volatility makes them difficult to supplement into culture media and the development of an applicable gasotransmitter treatment is subject to research. A serious consideration of gasotransmitters as signal molecules, respecting their evolutionary consequences, represents an expectation for current therapy of human reproduction.

\section{Abbreviations}

APC/C: Anaphase promoting factor/cyclosome

ART: Assisted reproductive technologies

CaMKII: Calmodulin-dependent protein kinase II

CBS: $\quad$ Cystathionine $\beta$-synthase

CDC25: Cell division cycle 25 phosphatase

CDKs: Cyclin-dependent kinases

CSE: $\quad$ Cystathionine $\gamma$-lyase

GAPDH: Glyceraldehyde 3-phosphate dehydrogenase

HDACs: Histone deacetylases

ICSI: Intracytoplasmic sperm injection

IVF: In vitro fertilization

MAPK: Mitogen-activated protein kinase

MEK1: MAPK/ERK kinase 1

MPF: $\quad$ M-phase/maturation promoting factor

3-MPST: 3-Mercaptopyruvate sulphurtransferase

NF- $\kappa$ B: Nuclear factor $\kappa$ B

eNOS: Endothelial nitric oxide (NO) synthase

nNOS: Neuronal nitric oxide (NO) synthase

iNOS: Inducible nitric oxide (NO) synthase

PKA: $\quad$ Protein kinase A

PKG: $\quad$ Protein kinase G

PLKs: Polo-like kinases

PTEN: Phosphatase and tensin homolog

PTP1B: Protein-tyrosine phosphatase 1B

ROS: $\quad$ Reactive oxygen species

RSS: $\quad$ Reactive sulfide species

sGC: $\quad$ Soluble guanylate cyclase

SIRT1: Sirtuin 1, SirT1, NAD ${ }^{+}$-dependent HDAC 1.

\section{Competing Interests}

The authors declare that there are no competing interests regarding the publication of this paper.

\section{Acknowledgments}

The research discussed in this review is founded by Charles University in Prague (PRVOUK P-36), the National Sustainability Program I (NPU I) no. LO1503 provided by the Ministry of Education, Youth and Sports of the Czech Republic, the National Agency of Agriculture Sciences (NAZV QJ1510138), and the Czech Ministry of Agriculture (MZeRO 0714). Jean-Francois Bodart is indebted to the Research Federation FRABio (Univ. Lille, CNRS, FR 3688, FRABio, Biochimie Structurale et Fonctionnelle des Assemblages Biomoléculaires) for providing the scientific and technical environment conducive to achieving herein mentioned work. The authors thank their long-time collaborators who have been working with them, including Drs. Tereza Zalmanova, Kristyna Hoskova, Radek Prochazka, and Tomas Kott and Professor Peter Sutovsky, as well as their graduate and postgraduate students.

\section{References}

[1] D. T. Armstrong, X. Zhang, B. C. Vanderhyden, and F. Khamsi, "Hormonal actions during oocyte maturation influence 
fertilization and early embryonic development," Annals of the New York Academy of Sciences, vol. 626, no. 1, pp. 137-158, 1991.

[2] P. Wassarman and D. F. Albertini, "The mammalian ovum," in The Physiology of Reproduction, E. Knobil and J. Neill, Eds., pp. 79-122, Raven Press, New York, NY, USA, 2nd edition, 1994.

[3] B. D. Bavister and J. M. Squirrell, "Mitochondrial distribution and function in oocytes and early embryos," Human Reproduction, vol. 15, no. 2, pp. 189-198, 2000.

[4] N. Suh and R. Blelloch, "Small RNAs in early mammalian development: from gametes to gastrulation," Development, vol. 138, no. 9, pp. 1653-1661, 2011.

[5] D. Keefe, M. Kumar, and K. Kalmbach, "Oocyte competency is the key to embryo potential," Fertility and Sterility, vol. 103, no. 2, pp. 317-322, 2015.

[6] W. Wang, M. Hosoe, R. Li, and Y. Shioya, "Development of the competence of bovine oocytes to release cortical granules and block polyspermy after meiotic maturation," Development Growth \& Differentiation, vol. 39, no. 5, pp. 607-615, 1997.

[7] G. M. Wessel, S. D. Conner, and L. Berg, "Cortical granule translocation is microfilament mediated and linked to meiotic maturation in the sea urchin oocyte," Development, vol. 129, no. 18, pp. 4315-4325, 2002.

[8] A. Ajduk, A. Małagocki, and M. Maleszewski, "Cytoplasmic maturation of mammalian oocytes: development of a mechanism responsible for sperm-induced $\mathrm{Ca}^{2+}$ oscillations," Reproductive Biology, vol. 8, no. 1, pp. 3-22, 2008.

[9] M. Cruz, B. Gadea, N. Garrido et al., "Embryo quality, blastocyst and ongoing pregnancy rates in oocyte donation patients whose embryos were monitored by time-lapse imaging," Journal of Assisted Reproduction and Genetics, vol. 28, no. 7, pp. 569-573, 2011.

[10] W. Zhou, L. Fu, W. Sha, D. Chu, and Y. Li, "Relationship of polar bodies morphology to embryo quality and pregnancy outcome," Zygote, vol. 24, no. 3, pp. 401-407, 2016.

[11] R. J. Webb, H. Bains, C. Cruttwell, and J. Carroll, "Gapjunctional communication in mouse cumulus-oocyte complexes: implications for the mechanism of meiotic maturation," Reproduction, vol. 123, no. 1, pp. 41-52, 2002.

[12] H.-Y. Fan, L.-J. Huo, X.-Q. Meng et al., "Involvement of calcium/calmodulin-dependent protein kinase II (CaMKII) in meiotic maturation and activation of pig oocytes," Biology of Reproduction, vol. 69, no. 5, pp. 1552-1564, 2003.

[13] C.-G. Liang, L.-J. Huo, Z.-S. Zhong, D.-Y. Chen, H. Schatten, and Q.-Y. Sun, "Cyclic adenosine 3/,5/-monophosphatedependent activation of mitogen-activated protein kinase in cumulus cells is essential for germinal vesicle breakdown of porcine cumulus-enclosed oocytes," Endocrinology, vol. 146, no. 10, pp. 4437-4444, 2005.

[14] D.-X. Zhang, W.-J. Park, S.-C. Sun et al., "Regulation of maternal gene expression by MEK/MAPK and MPF signaling in porcine oocytes during in vitro meiotic maturation," Journal of Reproduction and Development, vol. 57, no. 1, pp. 49-56, 2011.

[15] R. M. J. Palmer, A. G. Ferrige, and S. Moncada, "Nitric oxide release accounts for the biological activity of endotheliumderived relaxing factor," Nature, vol. 327, no. 6122, pp. 524-526, 1987.

[16] R. U. I. Wang, "Two's company, three's a crowd: can $\mathrm{H}_{2} \mathrm{~S}$ be the third endogenous gaseous transmitter?" The FASEB Journal, vol. 16, no. 13, pp. 1792-1798, 2002.
[17] L. Wu and R. Wang, "Carbon monoxide: endogenous production, physiological functions, and pharmacological applications," Pharmacological Reviews, vol. 57, no. 4, pp. 585-630, 2005.

[18] A. Jablonka-Shariff and L. M. Olson, "Nitric oxide is essential for optimal meiotic maturation of murine cumulus-oocyte complexes in vitro," Molecular Reproduction and Development, vol. 55, no. 4, pp. 412-421, 2000.

[19] R. Liang, W.-D. Yu, J.-B. Du, L.-J. Yang, M. Shang, and J.-Z. Guo, "Localization of cystathionine $\beta$ synthase in mice ovaries and its expression profile during follicular development," Chinese Medical Journal, vol. 119, no. 22, pp. 1877-1883, 2006.

[20] J. Nevoral, J. Petr, A. Gelaude et al., "Dual effects of hydrogen sulfide donor on meiosis and cumulus expansion of porcine cumulus-oocyte complexes," PLoS ONE, vol. 9, no. 7, Article ID e99613, 2014.

[21] S. Hashimoto, N. Minami, R. Takakura, and H. Imai, "Bovine immature oocytes acquire developmental competence during meiotic arrest in vitro," Biology of Reproduction, vol. 66, no. 6, pp. 1696-1701, 2002.

[22] R. Yanagimachi, "Mammalian fertilization," in The Physiology of Reproduction, E. Knobil and J. Neill, Eds., pp. 230-278, Raven Press, New York, NY, USA, 1988.

[23] K. H. Burns and M. M. Matzuk, "Preimplantation embryogenesis," in Knobil and Neill's Physiology of Reproduction, J. D. Neill, Ed., pp. 261-310, Elsevier, 3rd edition, 2006.

[24] L. J. Ignarro, "Endothelium-derived nitric oxide: pharmacology and relationship to the actions of organic nitrate esters," Pharmaceutical Research, vol. 6, no. 8, pp. 651-659, 1989.

[25] K. Shibuki and D. Okada, "Endogenous nitric oxide release required for long-term synaptic depression in the cerebellum," Nature, vol. 349, no. 6307, pp. 326-328, 1991.

[26] H. Kimura, "Hydrogen sulfide as a neuromodulator," Molecular Neurobiology, vol. 26, no. 1, pp. 13-19, 2002.

[27] Y. Cheng, J. F. Ndisang, G. Tang, K. Cao, and R. Wang, "Hydrogen sulfide-induced relaxation of resistance mesenteric artery beds of rats," American Journal of Physiology-Heart and Circulatory Physiology, vol. 287, no. 5, pp. H2316-H2323, 2004.

[28] Y. Shen, Z. Shen, S. Luo, W. Guo, and Y. Z. Zhu, "The cardioprotective effects of hydrogen sulfide in heart diseases: from molecular mechanisms to therapeutic potential," Oxidative Medicine and Cellular Longevity, vol. 2015, Article ID 925167, 13 pages, 2015.

[29] A. Jablonka-Shariff and L. M. Olson, "The role of nitric oxide in oocyte meiotic maturation and ovulation: meiotic abnormalities of endothelial nitric oxide synthase knock-out mouse oocytes," Endocrinology, vol. 139, no. 6, pp. 2944-2954, 1998.

[30] A. Jablonka-Shariff and L. M. Olson, "Hormonal regulation of nitric oxide synthases and their cell-specific expression during follicular development in the rat ovary," Endocrinology, vol. 138, no. 1, pp. 460-468, 1997.

[31] P. Pallares, R. A. Garcia-Fernandez, L. M. Criado et al., "Disruption of the endothelial nitric oxide synthase gene affects ovulation, fertilization and early embryo survival in a knockout mouse model," Reproduction, vol. 136, no. 5, pp. 573-579, 2008.

[32] E. Chmelíkov, M. Ješeta, M. Sedmíková et al., "Nitric oxide synthase isoforms and the effect of their inhibition on meiotic maturation of porcine oocytes," Zygote, vol. 18, no. 3, pp. 235244, 2010.

[33] J. Nevoral, T. Krejčová, J. Petr et al., “The role of nitric oxide synthase isoforms in aged porcine oocytes," Czech Journal of Animal Science, vol. 58, no. 10, pp. 453-459, 2013. 
[34] P. T. Goud, A. P. Goud, T. Najafi et al., "Direct real-time measurement of intra-oocyte nitric oxide concentration in vivo," PLoS ONE, vol. 9, no. 6, article e98720, 2014.

[35] C.-S. Ha, B.-S. Joo, S.-C. Kim, J.-K. Joo, H.-G. Kim, and K.-S. Lee, "Estrogen administration during superovulation increases oocyte quality and expressions of vascular endothelial growth factor and nitric oxide synthase in the ovary," Journal of Obstetrics and Gynaecology Research, vol. 36, no. 4, pp. 789-795, 2010.

[36] J. Romero-Aguirregomezcorta, Á. P. Santa, F. A. GarcíaVázquez, P. Coy, and C. Matás, "Nitric Oxide Synthase (NOS) inhibition during porcine in vitro maturation modifies oocyte protein S-nitrosylation and in vitro fertilization," PLoS ONE, vol. 9, no. 12, Article ID e115044, 2014.

[37] W. R. Montfort, J. A. Wales, and A. Weichsel, "Structure and activation of soluble guanylyl cyclase, the nitric oxide sensor," Antioxidants \& Redox Signaling, 2016.

[38] S. Bilodeau-Goeseels, "Effects of manipulating the nitric oxide/cyclic GMP pathway on bovine oocyte meiotic resumption in vitro," Theriogenology, vol. 68, no. 5, pp. 693-701, 2007.

[39] B. P. Carreira, M. I. Morte, A. S. Lourenço et al., "Differential contribution of the guanylyl cyclase-cyclic GMP-Protein kinase $G$ pathway to the proliferation of neural stem cells stimulated by nitric oxide," NeuroSignals, vol. 21, no. 1-2, pp. 1-13, 2013.

[40] S. A. Stricker, "Inhibition of germinal vesicle breakdown by antioxidants and the roles of signaling pathways related to nitric oxide and cGMP during meiotic resumption in oocytes of a marine worm," Reproduction, vol. 143, no. 3, pp. 261-270, 2012.

[41] N. Sayed, P. Baskaran, X. Ma, F. Van Den Akker, and A. Beuve, "Desensitization of soluble guanylyl cyclase, the NO receptor, by S-nitrosylation," Proceedings of the National Academy of Sciences of the United States of America, vol. 104, no. 30, pp. 12312-12317, 2007.

[42] J. Petr, R. Rajmon, E. Chmelíková et al., "Nitric-oxidedependent activation of pig oocytes: the role of the cGMPsignalling pathway," Zygote, vol. 14, no. 1, pp. 9-16, 2006.

[43] J. Petr, E. Chmelíková, T. Krejčová, D. Řehák, B. Novotná, and F. Jílek, "Parthenogenetic activation of pig oocytes using pulsatile treatment with a nitric oxide donor," Reproduction in Domestic Animals, vol. 45, no. 3, pp. 493-499, 2010.

[44] M. Jeseta, M. Marin, H. Tichovska et al., "Nitric oxide-donor SNAP induces xenopus eggs activation," PLoS ONE, vol. 7, no. 7, article e41509, 2012.

[45] R. C. Kuo, G. T. Baxter, S. H. Thompson et al., "NO is necessary and sufficient for egg activation at fertilization," Nature, vol. 406, no. 6796, pp. 633-636, 2000.

[46] L. Tůmová, R. Romar, J. Petr, and M. Sedmíková, “The effect of protein kinase $\mathrm{C}$ activator and nitric oxide donor on oocyte activation and cortical granule exocytosis in porcine eggs," Animal, vol. 7, no. 2, pp. 279-286, 2013.

[47] A. Predonzani, B. Cali, A. H. Agnellini et al., "Spotlights on immunological effects of reactive nitrogen species: when inflammation says nitric oxide," World Journal of Experimental Medicine, vol. 5, no. 2, pp. 64-76, 2015.

[48] D. Modun, D. Giustarini, and D. Tsikas, "Nitric oxide-related oxidative stress and redox status in health and disease," Oxidative Medicine and Cellular Longevity, vol. 2014, Article ID 129651, 3 pages, 2014.

[49] Q. Luo, X.-J. Chen, G.-L. Ding, M.-Y. Dong, and H.-F. Huang, "Downregulative effects of nitric oxide on oocyte fertilization and embryo development: possible roles of nitric oxide in the pathogenesis of endometriosis-associated infertility," Cellular Physiology and Biochemistry, vol. 26, no. 6, pp. 1023-1028, 2010.

[50] T.-H. Lee, M.-S. Lee, C.-C. Huang et al., "Nitric oxide modulates mitochondrial activity and apoptosis through protein Snitrosylation for preimplantation embryo development," Journal of Assisted Reproduction and Genetics, vol. 30, no. 8, pp. 1063-1072, 2013.

[51] K. R. L. Schwarz, P. R. L. Pires, T. H. C. de Bem, P. R. Adona, and C. L. V. Leal, "Consequences of nitric oxide synthase inhibition during bovine oocyte maturation on meiosis and embryo development," Reproduction in Domestic Animals, vol. 45, no. 1, pp. 75-80, 2010.

[52] P. T. Goud, A. P. Goud, N. Joshi, E. Puscheck, M. P. Diamond, and H. M. Abu-Soud, "Dynamics of nitric oxide, altered follicular microenvironment, and oocyte quality in women with endometriosis," Fertility and Sterility, vol. 102, no. 1, pp. 151159.e5, 2014.

[53] M. Dong, Y. Shi, Q. Cheng, and M. Hao, "Increased nitric oxide in peritoneal fluid from women with idiopathic infertility and endometriosis," Journal of Reproductive Medicine for the Obstetrician and Gynecologist, vol. 46, no. 10, pp. 887-891, 2001.

[54] P. Goud, A. Goud, and M. Diamond, "Chronological age enhances oocyte post ovulatory aging, protein nitration and nitric oxide insufficiency in oocytes and their microenvironment," Fertility and Sterility, vol. 102, no. 3, p. e329, 2014.

[55] S. N. Khan, F. Shaeib, M. Thakur et al., "Peroxynitrite deteriorates oocyte quality through disassembly of microtubule organizing centers," Free Radical Biology and Medicine, vol. 91, pp. 275-280, 2016.

[56] S. Mora-Castilla, J. R. Tejedo, A. Hmadcha et al., "Nitric oxide repression of nanog promotes mouse embryonic stem cell differentiation," Cell Death \& Differentiation, vol. 17, no. 6, pp. 1025-1033, 2010.

[57] A. K. Mustafa, M. M. Gadalla, N. Sen et al., " $\mathrm{H}_{2} \mathrm{~S}$ signals through protein S-sulfhydration," Science Signaling, vol. 2, no. 96, article ra72, 2009.

[58] H. Kimura, "The physiological role of hydrogen sulfide and beyond," Nitric Oxide, vol. 41, pp. 4-10, 2014.

[59] J. Nevoral, T. Žalmanová, K. Zámostná et al., "Endogenously produced hydrogen sulfide is involved in porcine oocyte maturation in vitro," Nitric Oxide, vol. 51, pp. 24-35, 2015.

[60] T. Krejcova, M. Smelcova, J. Petr et al., "Hydrogen sulfide donor protects porcine oocytes against aging and improves the developmental potential of aged porcine oocytes," PLoS ONE, vol. 10, no. 1, Article ID e0116964, 2015.

[61] K. Zhao, Y. Ju, S. Li, Z. Altaany, R. Wang, and G. Yang, "Ssulfhydration of MEK1 leads to PARP-1 activation and DNA damage repair," EMBO Reports, vol. 15, no. 7, pp. 792-800, 2014.

[62] T. V. Mishanina, M. Libiad, and R. Banerjee, "Biogenesis of reactive sulfur species for signaling by hydrogen sulfide oxidation pathways," Nature Chemical Biology, vol. 11, no. 7, pp. 457-464, 2015.

[63] E. R. DeLeon, Y. Gao, E. Huang et al., "A case of mistaken identity: are reactive oxygen species actually reactive sulfide species?" American Journal of Physiology-Regulatory, Integrative and Comparative Physiology, vol. 310, no. 7, pp. R549-R560, 2016.

[64] P. K. Yadav, M. Martinov, V. Vitvitsky et al., "Biosynthesis and reactivity of cysteine persulfides in signaling," Journal of the American Chemical Society, vol. 138, no. 1, pp. 289-299, 2016. 
[65] A. Martínez-Ruiz and S. Lamas, "S-nitrosylation: a potential new paradigm in signal transduction," Cardiovascular Research, vol. 62, no. 1, pp. 43-52, 2004.

[66] C. Gao, H. Guo, J. Wei, Z. Mi, P. Y. Wai, and P. C. Kuo, "Identification of S-nitrosylated proteins in endotoxin-stimulated RAW264.7 murine macrophages," Nitric Oxide-Biology and Chemistry, vol. 12, no. 2, pp. 121-126, 2005.

[67] L. Lefièvre, Y. Chen, S. J. Conner et al., "Human spermatozoa contain multiple targets for protein S-nitrosylation: an alternative mechanism of the modulation of sperm function by nitric oxide?" Proteomics, vol. 7, no. 17, pp. 3066-3084, 2007.

[68] H. Stroissnigg, A. Trančíková, L. Descovich et al., "Snitrosylation of microtubule-associated protein $1 \mathrm{~B}$ mediates nitric-oxide-induced axon retraction," Nature Cell Biology, vol. 9, no. 9, pp. 1035-1045, 2007.

[69] M. Grau, S. Pauly, J. Ali et al., "RBC-NOS-dependent Snitrosylation of cytoskeletal proteins improves RBC deformability," PLoS ONE, vol. 8, no. 2, Article ID e56759, 2013.

[70] H. Kimura, "Production and physiological effects of hydrogen sulfide," Antioxidants \& Redox Signaling, vol. 20, no. 5, pp. 783793, 2014.

[71] M. W. Foster, M. T. Forrester, and J. S. Stamler, "A protein microarray-based analysis of S-nitrosylation," Proceedings of the National Academy of Sciences of the United States of America, vol. 106, no. 45, pp. 18948-18953, 2009.

[72] S. Kumar, M. K. Barthwal, and M. Dikshit, "Cdk2 nitrosylation and loss of mitochondrial potential mediate NO-dependent biphasic effect on HL-60 cell cycle," Free Radical Biology and Medicine, vol. 48, no. 6, pp. 851-861, 2010.

[73] S. Ben-Lulu, T. Ziv, A. Admon, P. Weisman-Shomer, and M. Benhar, "A substrate trapping approach identifies proteins regulated by reversible S-nitrosylation," Molecular and Cellular Proteomics, vol. 13, no. 10, pp. 2573-2583, 2014.

[74] U. Majumdar, P. Biswas, T. S. Sarkar, D. Maiti, and S. Ghosh, "Regulation of cell cycle and stress responses under nitrosative stress in Schizosaccharomyces pombe," Free Radical Biology and Medicine, vol. 52, no. 11-12, pp. 2186-2200, 2012.

[75] W. Guo, J.-T. Kan, Z.-Y. Cheng et al., "Hydrogen sulfide as an endogenous modulator in mitochondria and mitochondria dysfunction," Oxidative Medicine and Cellular Longevity, vol. 2012, Article ID 878052, 9 pages, 2012.

[76] J. E. Cartwright, D. P. Holden, and G. S. J. Whitley, "Hepatocyte growth factor regulates human trophoblast motility and invasion: a role for nitric oxide," British Journal of Pharmacology, vol. 128, no. 1, pp. 181-189, 1999.

[77] J. E. Cartwright, W. K. Tse, and G. S. J. Whitley, "Hepatocyte growth factor induced human trophoblast motility involves phosphatidylinositol-3-kinase, mitogen-activated protein kinase, and inducible nitric oxide synthase," Experimental Cell Research, vol. 279, no. 2, pp. 219-226, 2002.

[78] L. K. Harris, J. McCormick, J. E. Cartwright, G. S. J. Whitley, and P. R. Dash, "S-nitrosylation of proteins at the leading edge of migrating trophoblasts by inducible nitric oxide synthase promotes trophoblast invasion," Experimental Cell Research, vol. 314, no. 8, pp. 1765-1776, 2008.

[79] Z. Gu, M. Kaul, B. Yan et al., "S-nitrosylation of matrix metalloproteinases: signaling pathway to neuronal cell death," Science, vol. 297, no. 5584, pp. 1186-1190, 2002.

[80] P. R. Dash, J. E. Cartwright, P. N. Baker, A. P. Johnstone, and G. S. J. Whitley, "Nitric oxide protects human extravillous trophoblast cells from apoptosis by a cyclic GMP-dependent mechanism and independently of caspase 3 nitrosylation," Experimental Cell Research, vol. 287, no. 2, pp. 314-324, 2003.

[81] C. Lu, A. Kavalier, E. Lukyanov, and S. S. Gross, "Ssulfhydration/desulfhydration and S-nitrosylation/denitrosylation: a common paradigm for gasotransmitter signaling by $\mathrm{H}_{2} \mathrm{~S}$ and NO," Methods, vol. 62, no. 2, pp. 177-181, 2013.

[82] N. Sen, B. D. Paul, M. M. Gadalla et al., "Hydrogen sulfidelinked sulfhydration of NF- $\kappa$ B mediates its antiapoptotic actions," Molecular Cell, vol. 45, no. 1, pp. 13-24, 2012.

[83] W. Zhang, C. Xu, G. Yang, L. Wu, and R. Wang, "Interaction of $\mathrm{H}_{2} \mathrm{~S}$ with calcium permeable channels and transporters," Oxidative Medicine and Cellular Longevity, vol. 2015, Article ID 323269, 7 pages, 2015.

[84] M. R. Filipovic, "Persulfidation (S-sulfhydration) and $\mathrm{H}_{2} \mathrm{~S}$," in Chemistry, Biochemistry and Pharmacology of Hydrogen Sulfide, vol. 230 of Handbook of Experimental Pharmacology, pp. 29-59, Springer, Berlin, Germany, 2015.

[85] A. Di Cristofano, B. Pesce, C. Cordon-Cardo, and P. P. Pandolfi, "Pten is essential for embryonic development and tumour suppression," Nature Genetics, vol. 19, no. 4, pp. 348-355, 1998.

[86] K. Ohno, K. Okuda, and T. Uehara, "Endogenous Ssulfhydration of PTEN helps protect against modification by nitric oxide," Biochemical and Biophysical Research Communications, vol. 456, no. 1, pp. 245-249, 2015.

[87] Y.-D. Kwak, T. Ma, S. Diao et al., "NO signaling and Snitrosylation regulate PTEN inhibition in neurodegeneration," Molecular Neurodegeneration, vol. 5, article 49, pp. 10349-10354, 2010.

[88] N. Krishnan, C. Fu, D. J. Pappin, and N. K. Tonks, "Biochemistry: $\mathrm{H}_{2} \mathrm{~S}$-induced sulfhydration of the phosphatase PTP1B and its role in the endoplasmic reticulum stress response," Science Signaling, vol. 4, no. 203, article ra86, 2011.

[89] J. Rudolph, "Redox regulation of the Cdc25 phosphatases," Antioxidants and Redox Signaling, vol. 7, no. 5-6, pp. 761-767, 2005.

[90] E. Viry, A. Anwar, G. Kirsch, C. Jacob, M. Diederich, and D. Bagrel, "Antiproliferative effect of natural tetrasulfides in human breast cancer cells is mediated through the inhibition of the cell division cycle 25 phosphatases," International Journal of Oncology, vol. 38, no. 4, pp. 1103-1111, 2011.

[91] P. Heneberg, "Reactive nitrogen species and hydrogen sulfide as regulators of protein tyrosine phosphatase activity," Antioxidants and Redox Signaling, vol. 20, no. 14, pp. 2191-2209, 2014.

[92] M. R. Hara, N. Agrawal, S. F. Kim et al., "S-nitrosylated GAPDH initiates apoptotic cell death by nuclear translocation following Siahl binding," Nature Cell Biology, vol. 7, no. 7, pp. 665-674, 2005.

[93] T. M. Greco, R. Hodara, I. Parastatidis et al., "Identification of S-nitrosylation motifs by site-specific mapping of the Snitrosocysteine proteome in human vascular smooth muscle cells," Proceedings of the National Academy of Sciences of the United States of America, vol. 103, no. 19, pp. 7420-7425, 2006.

[94] G. Hao, B. Derakhshan, L. Shi, F. Campagne, and S. S. Gross, "SNOSID, a proteomic method for identification of cysteine Snitrosylation sites in complex protein mixtures," Proceedings of the National Academy of Sciences of the United States of America, vol. 103, no. 4, pp. 1012-1017, 2006.

[95] K. K. K. Chung, B. Thomas, X. Li et al., "S-nitrosylation of parkin regulates ubiquitination and compromises parkin's protective function," Science, vol. 304, no. 5675, pp. 1328-1331, 2004 . 
[96] M. S. Vandiver, B. D. Paul, R. Xu et al., "Sulfhydration mediates neuroprotective actions of parkin," Nature Communications, vol. 4, article 1626, 2013.

[97] J. Du, Y. Huang, H. Yan et al., "Hydrogen sulfide suppresses oxidized low-density lipoprotein (Ox-LDL)-stimulated monocyte chemoattractant protein 1 generation from macrophages via the nuclear factor $\kappa \mathrm{b}$ (NF- $\kappa \mathrm{B}$ ) pathway," Journal of Biological Chemistry, vol. 289, no. 14, pp. 9741-9753, 2014.

[98] J. P. Nicola, V. Peyret, M. Nazar et al., "S-nitrosylation of NF$\kappa \mathrm{B}$ p65 inhibits TSH-induced $\mathrm{Na}^{+} / \mathrm{I}^{-}$symporter expression," Endocrinology, vol. 156, no. 12, pp. 4741-4754, 2015.

[99] Z. T. Kelleher, E. N. Potts, M. V. Brahmajothi et al., "NOS2 regulation of LPS-induced airway inflammation via S-nitrosylation of NF- $\kappa$ B p65," American Journal of Physiology-Lung Cellular and Molecular Physiology, vol. 301, no. 3, pp. L327-L333, 2011.

[100] I. Dalle-Donne, A. Milzani, D. Giustarini, P. Di Simplicio, R. Colombo, and R. Rossi, "S-NO-actin: S-nitrosylation kinetics and the effect on isolated vascular smooth muscle," Journal of Muscle Research \& Cell Motility, vol. 21, no. 2, pp. 171-181, 2000.

[101] S. R. Thom, V. M. Bhopale, D. J. Mancini, and T. N. Milovanova, "Actin S-nitrosylation inhibits neutrophil $\beta 2$ integrin function," The Journal of Biological Chemistry, vol. 283, no. 16, pp. 1082210834, 2008.

[102] H.-H. Zhang, T. J. Lechuga, T. Tith, W. Wang, D. A. Wing, and D.-B. Chen, "S-nitrosylation of cofilin-1 mediates estradiol$17 \beta$ stimulated endothelial cytoskeleton remodeling," Molecular Endocrinology, vol. 29, no. 3, pp. 434-444, 2015.

[103] Z. Altaany, Y. J. Ju, G. Yang, and R. Wang, “The coordination of S-sulfhydration, S-nitrosylation, and phosphorylation of endothelial nitric oxide synthase by hydrogen sulfide," Science Signaling, vol. 7, no. 342, article ra87, 2014.

[104] B. Kloesch, G. Steiner, B. Mayer, and K. Schmidt, "Hydrogen sulfide inhibits endothelial nitric oxide formation and receptor ligand-mediated $\mathrm{Ca}^{2+}$ release in endothelial and smooth muscle cells," Pharmacological Reports, vol. 68, no. 1, pp. 37-43, 2016.

[105] Z. P. Nagy, C. Janssenswillen, R. Janssens et al., "Timing of oocyte activation, pronucleus formation and cleavage in humans after intracytoplasmic sperm injection (ICSI) with testicular spermatozoa and after ICSI or in-vitro fertilization on sibling oocytes with ejaculated spermatozoa," Human Reproduction, vol. 13, no. 6, pp. 1606-1612, 1998.

[106] L. Papale, A. Fiorentino, M. Montag, and G. Tomasi, "The zygote," Human Reproduction, vol. 27, supplement 1, pp. i22-i49, 2012.

[107] Z. Han, N. R. Mtango, Z. Zhong, R. Vassena, and K. E. Latham, "Early transcription from the maternal genome controlling blastomere integrity in mouse two-cell-stage embryos," American Journal of Physiology-Cell Physiology, vol. 298, no. 5, pp. C1235-C1244, 2010.

[108] L. Petrussa, H. Van de Velde, and M. De Rycke, "Dynamic regulation of DNA methyltransferases in human oocytes and preimplantation embryos after assisted reproductive technologies," Molecular Human Reproduction, vol. 20, no. 9, pp. 861-874, 2014.

[109] J. Mao, M.-T. Zhao, K. M. Whitworth et al., "Oxamflatin treatment enhances cloned porcine embryo development and nuclear reprogramming," Cellular Reprogramming, vol. 17, no. 1, pp. 28-40, 2015.

[110] K. R. L. Schwarz, P. R. L. Pires, P. R. Adona, T. H. Câmara De Bem, and C. L. V. Leal, "Influence of nitric oxide during maturation on bovine oocyte meiosis and embryo development in vitro," Reproduction, Fertility and Development, vol. 20, no. 4, pp. 529-536, 2008.

[111] B. H. Kim, C. H. Kim, K. Y. Jung et al., "Involvement of nitric oxide duringin vitro fertilization and early embryonic development in mice," Archives of Pharmacal Research, vol. 27, no. 1, pp. 86-93, 2004.

[112] P. T. Goud, A. P. Goud, M. P. Diamond, B. Gonik, and H. M. Abu-Soud, "Nitric oxide extends the oocyte temporal window for optimal fertilization," Free Radical Biology and Medicine, vol. 45, no. 4, pp. 453-459, 2008.

[113] S. G. C. Matta, M. C. Caldas-Bussiere, K. S. Viana et al., "Effect of inhibition of synthesis of inducible nitric oxide synthase-derived nitric oxide by aminoguanidine on the in vitro maturation of oocyte-cumulus complexes of cattle," Animal Reproduction Science, vol. 111, no. 2, pp. 189-201, 2009.

[114] J. Petr, R. Rajmon, J. Rozinek et al., "Activation of pig oocytes using nitric oxide donors," Molecular Reproduction and Development, vol. 71, no. 1, pp. 115-122, 2005.

[115] A. S. Haqqani, J. F. Kelly, and H. Chaim Birnboim, "Selective nitration of histone tyrosine residues in vivo in mutatect tumors," The Journal of Biological Chemistry, vol. 277, no. 5, pp. 3614-3621, 2002.

[116] A. F. Vanin and V. I. Ivanov, "Interaction of iron ions with oxygen or nitrogen monoxide in chromosomes triggers synchronous expression/suppression oscillations of compact gene groups ('genomewide oscillation'): hypothesis," Nitric OxideBiology and Chemistry, vol. 18, no. 3, pp. 147-152, 2008.

[117] B. Illi, C. Colussi, A. Grasselli, A. Farsetti, M. C. Capogrossi, and C. Gaetano, "NO sparks off chromatin: tales of a multifaceted epigenetic regulator," Pharmacology \& Therapeutics, vol. 123, no. 3, pp. 344-352, 2009.

[118] A. H. F. M. Peters, J. E. Mermoud, D. O’Carroll et al., "Histone $\mathrm{H} 3$ lysine 9 methylation is an epigenetic imprint of facultative heterochromatin," Nature Genetics, vol. 30, no. 1, pp. 77-80, 2002.

[119] A. Vaquero, M. Scher, D. Lee, H. Erdjument-Bromage, P. Tempst, and D. Reinberg, "Human SirT1 interacts with histone $\mathrm{H} 1$ and promotes formation of facultative heterochromatin," Molecular Cell, vol. 16, no. 1, pp. 93-105, 2004.

[120] P. M. D. Watson and A. Riccio, "Nitric oxide and histone deacetylases: a new relationship between old molecules," Communicative and Integrative Biology, vol. 2, no. 1, pp. 11-13, 2009.

[121] H. Ota, M. Eto, S. Ogawa, K. Iijima, M. Akishita, and Y. Ouchi, "Sirt1/eNOS axis as a potential target against vascular senescence, dysfunction and atherosclerosis," Journal of Atherosclerosis and Thrombosis, vol. 17, no. 5, pp. 431-435, 2010.

[122] Z. Shang, C. Lu, S. Chen, L. Hua, and R. Qian, "Effect of $\mathrm{H}_{2} \mathrm{~S}$ on the circadian rhythm of mouse hepatocytes," Lipids in Health and Disease, vol. 11, article 23, 2012.

[123] G. Yetik-Anacak, M. V. Dereli, G. Sevin, O. Ozzayim, Y. Erac, and A. Ahmed, "Resveratrol Stimulates Hydrogen Sulfide $\left(\mathrm{H}_{2} \mathrm{~S}\right)$ formation to relax murine corpus cavernosum," The Journal of Sexual Medicine, vol. 12, no. 10, pp. 2004-2012, 2015.

[124] A. A. Sauve, I. Celic, J. Avalos, H. Deng, J. D. Boeke, and V. L. Schramm, "Chemistry of gene silencing: the mechanism of NAD+-dependent deacetylation reactions," Biochemistry, vol. 40, no. 51, pp. 15456-15463, 2001.

[125] M. C. Motta, N. Divecha, M. Lemieux et al., "Mammalian SIRT1 represses forkhead transcription factors," Cell, vol. 116, no. 4, pp. 551-563, 2004. 
[126] A. Vaquero, M. Scher, H. Erdjument-Bromage, P. Tempst, L. Serrano, and D. Reinberg, "SIRT1 regulates the histone methyl-transferase SUV39H1 during heterochromatin formation," Nature, vol. 450, no. 7168, pp. 440-444, 2007.

[127] J. Nevoral, P. Sutovsky, K. Zamostna et al., "SIRT1 as a key factor for histone code establishment in early embryo, from a perspective of assisted reproduction," Slovak Journal of Animal Science, vol. 48, no. 4, pp. 145-158, 2015.

[128] E. C. S. Rios, B. Szczesny, F. G. Soriano, G. Olah, and C. Szabo, "Hydrogen sulfide attenuates cytokine production through the modulation of chromatin remodeling," International Journal of Molecular Medicine, vol. 35, no. 6, pp. 1741-1746, 2015.

[129] R. Tapia-Limonchi, G. M. Cahuana, E. Caballano-Infantes et al., "Nitric oxide prevents mouse embryonic stem cell differentiation through regulation of gene expression, cell signaling, and control of cell proliferation," Journal of Cellular Biochemistry, vol. 117, no. 9, pp. 2078-2088, 2016.

[130] W. Guan, J. Sha, X. Chen, Y. Xing, J. Yan, and Z. Wang, "SNitrosylation of mitogen activated protein kinase phosphatase1 suppresses radiation-induced apoptosis," Cancer Letters, vol. 314, no. 2, pp. 137-146, 2012.

[131] X. Feng, T. Sun, Y. Bei et al., "S-nitrosylation of ERK inhibits ERK phosphorylation and induces apoptosis," Scientific Reports, vol. 3, article 1814, 2013.

[132] P. Stein, D. M. Worrad, N. D. Belyaev, B. M. Turner, and R. M. Schultz, "Stage-dependent redistributions of acetylated histones in nuclei of the early preimplantation mouse embryo," Molecular Reproduction and Development, vol. 47, no. 4, pp. 421429, 1997.

[133] S. J. Bultman, T. C. Gebuhr, H. Pan, P. Svoboda, R. M. Schultz, and T. Magnuson, "Maternal BRG1 regulates zygotic genome activation in the mouse," Genes \& Development, vol. 20, no. 13, pp. 1744-1754, 2006.

[134] J. A. Dahl, A. H. Reiner, A. Klungland, T. Wakayama, and P. Collas, "Histone H3 lysine 27 methylation asymmetry on developmentally-regulated promoters distinguish the first two lineages in mouse preimplantation embryos," PLoS ONE, vol. 5, no. 2, article e9150, 2010.

[135] A. Bošković, A. Bender, L. Gall, C. Ziegler-Birling, N. Beaujean, and M.-E. Torres-Padilla, "Analysis of active chromatin modifications in early mammalian embryos reveals uncoupling of H2A.Z acetylation and H3K36 trimethylation from embryonic genome activation," Epigenetics, vol. 7, no. 7, pp. 747-757, 2012.

[136] K. Okuda, A. Ito, and T. Uehara, "Regulation of histone deacetylase 6 activity via S-nitrosylation," Biological and Pharmaceutical Bulletin, vol. 38, no. 9, pp. 1434-1437, 2015.

[137] H. Xin, M. Wang, W. Tang et al., "Hydrogen sulfide attenuates inflammatory hepcidin by reducing IL-6 secretion and promoting SIRT1-mediated STAT3 deacetylation," Antioxidants \& Redox Signaling, vol. 24, no. 2, pp. 70-83, 2016.

[138] K. R. Olson, J. A. Donald, R. A. Dombkowski, and S. F. Perry, "Evolutionary and comparative aspects of nitric oxide, carbon monoxide and hydrogen sulfide," Respiratory Physiology \& Neurobiology, vol. 184, no. 2, pp. 117-129, 2012.

[139] P. Yuan, H. Xue, L. Zhou et al., "Rescue of mesangial cells from high glucose-induced over-proliferation and extracellular matrix secretion by hydrogen sulfide," Nephrology Dialysis Transplantation, vol. 26, no. 7, pp. 2119-2126, 2011.

[140] C. Szabo, C. Coletta, C. Chao et al., "Tumor-derived hydrogen sulfide, produced by cystathionine- $\beta$-synthase, stimulates bioenergetics, cell proliferation, and angiogenesis in colon cancer," Proceedings of the National Academy of Sciences of the United States of America, vol. 110, no. 30, pp. 12474-12479, 2013.

[141] L. Li, D. Liu, D. Bu et al., "Brg1-dependent epigenetic control of vascular smooth muscle cell proliferation by hydrogen sulfide," Biochimica et Biophysica Acta-Molecular Cell Research, vol. 1833, no. 6, pp. 1347-1355, 2013.

[142] F. Guo, X. Li, D. Liang et al., "Active and passive demethylation of male and female pronuclear DNA in the mammalian zygote," Cell Stem Cell, vol. 15, no. 4, pp. 447-458, 2014.

[143] R. Yang, C. Qu, Y. Zhou et al., "Hydrogen sulfide promotes Tet1and Tet2-mediated Foxp3 demethylation to drive regulatory $\mathrm{T}$ cell differentiation and maintain immune homeostasis," Immunity, vol. 43, no. 2, pp. 251-263, 2015.

[144] X. Pan, X. Wang, X. Wang et al., "Nitric oxide regulates blastocyst hatching in mice," International Journal of Clinical and Experimental Medicine, vol. 8, no. 5, pp. 6994-7001, 2015.

[145] Y. Huang, C. Tang, J. Du, and H. Jin, "Endogenous sulfur dioxide: a new member of gasotransmitter family in the cardiovascular system," Oxidative Medicine and Cellular Longevity, vol. 2016, Article ID 8961951, 9 pages, 2016.

[146] D.-B. Zhu, K.-D. Hu, X.-K. Guo et al., "Sulfur dioxide enhances endogenous hydrogen sulfide accumulation and alleviates oxidative stress induced by aluminum stress in germinating wheat seeds," Oxidative Medicine and Cellular Longevity, vol. 2015, Article ID 612363, 11 pages, 2015.

[147] Q. Jin, K. Zhu, W. Cui, Y. Xie, B. Han, and W. Shen, "Hydrogen gas acts as a novel bioactive molecule in enhancing plant tolerance to paraquat-induced oxidative stress via the modulation of heme oxygenase-1 signalling system," Plant, Cell \& Environment, vol. 36, no. 5, pp. 956-969, 2013.

[148] S. Xu, S. Zhu, Y. Jiang et al., "Hydrogen-rich water alleviates salt stress in rice during seed germination," Plant and Soil, vol. 370, no. 1-2, pp. 47-57, 2013. 


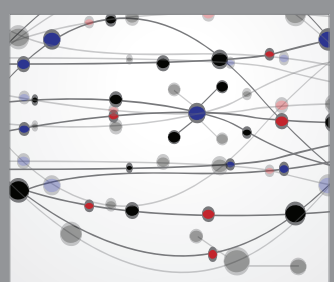

The Scientific World Journal
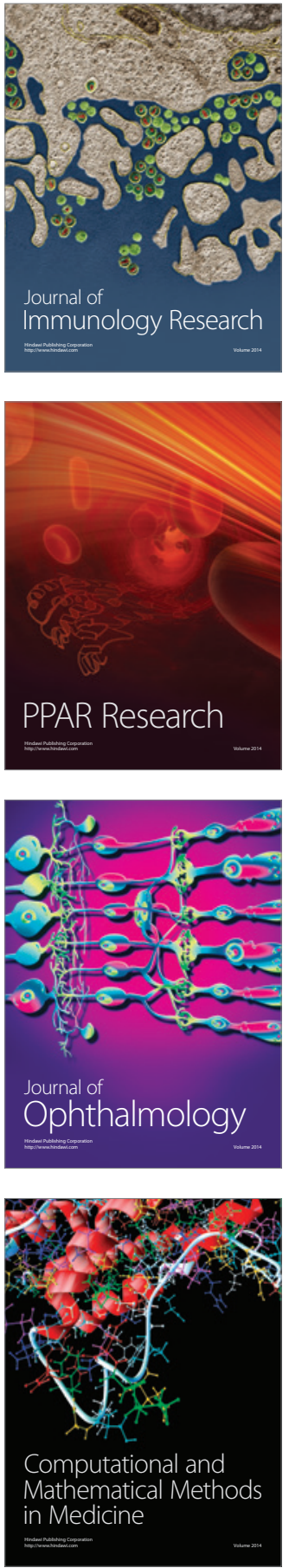

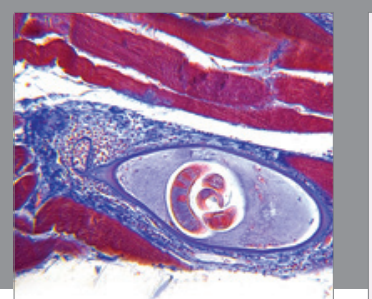

Gastroenterology Research and Practice

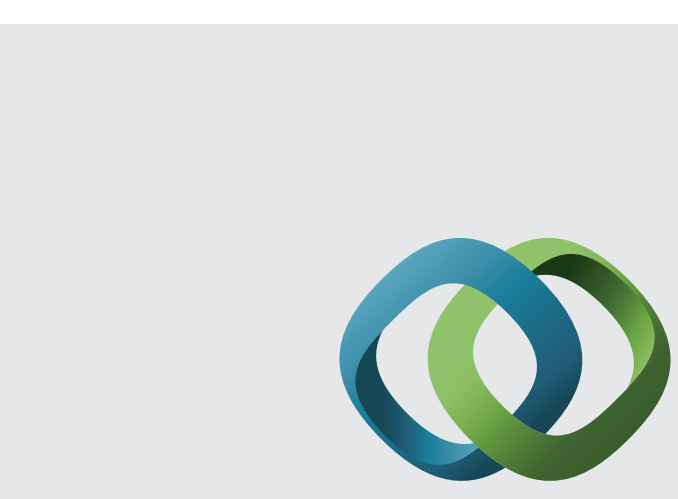

\section{Hindawi}

Submit your manuscripts at

http://www.hindawi.com
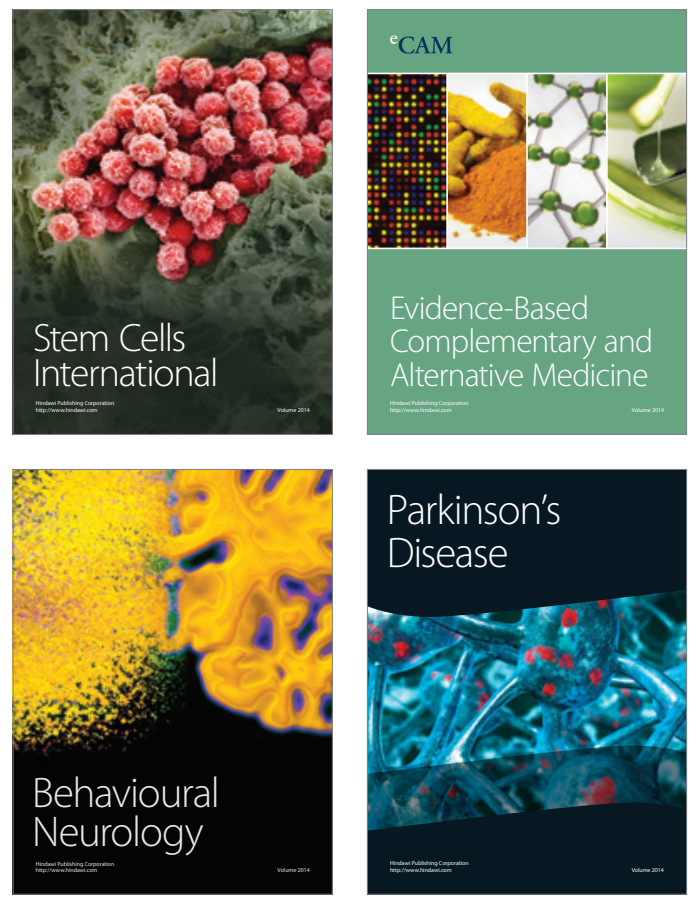
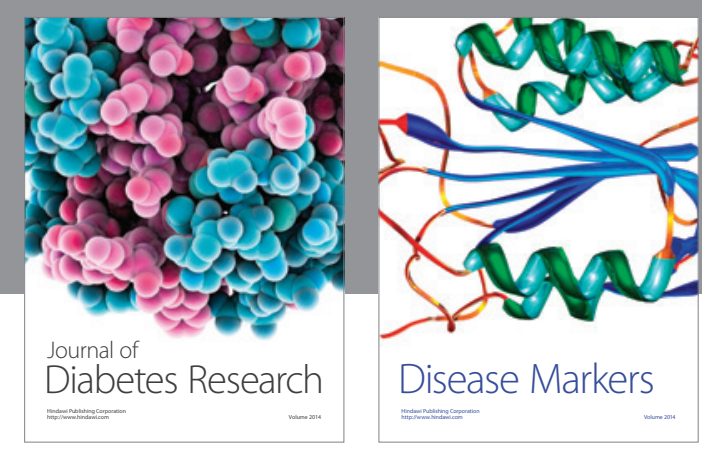

Disease Markers
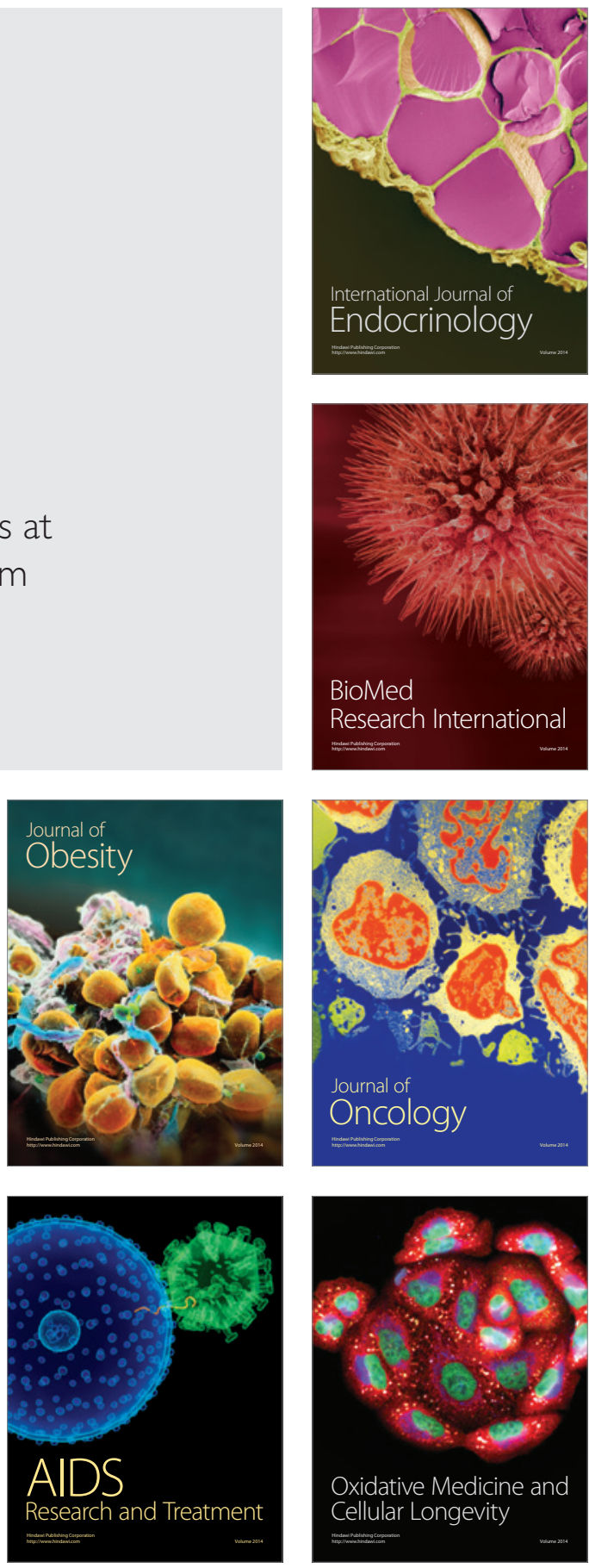